\title{
Instinto de repórter
}

LOBATO, Elvira. Instinto de repórter. São Paulo: Publifolha, 2005.

\section{Gerson Moreira Lima}

Professor Doutor pela Universidade de São Paulo (USP), ministra aulas na Universidade Católica de Santos (Unisantos) e na Universidade Santa Cecília (Unisanta), Santos, SP - Brasil, e-mail: gerson1952@uol.com.br

Em 35 anos de carreira, a jornalista Elvira Lobato sempre acreditou que os jornais não recusam boas reportagens e que "a curiosidade e o entusiasmo são os requisitos essenciais do repórter", como deixa claro já na introdução do seu livro Instinto de repórter, da Publifolha, lançado em 2005, mas que apenas agora começa a ser descoberto pela comunidade acadêmica. Provavelmente pelos frequentes debates na Academia sobre novos rumos do jornalismo - especialmente o impresso -, que apontam para o resgate das grandes reportagens, entre elas as chamadas matérias de investigação.

O trabalho de Elvira refere-se a reportagens produzidas ao longo de 19 anos de atuação na Folha de S. Paulo, inicialmente como repórter da sucursal do Rio de Janeiro, onde ingressou em outubro de 1984, e, em seguida, como repórter especial subordinada à direção de redação, a partir de 1991.

Como a própria repórter registra, é um livro voltado para os jovens que se preparam para entrar no mercado de trabalho e para os não tão jovens que são apaixonados pela profissão de repórter.

Cabe-nos incluir nesse rol a centena de professores de redação e reportagem das universidades brasileiras, mais especificamente aqueles que insistem em trabalhar em classe com o gênero (permitimo-nos o uso de tal classificação) investigativo, relegado a artigo raro nos bancos universitários, embora indispensável.

Para aqueles que se utilizam do discurso simplista de que o jornalismo investigativo é um rótulo desnecessário porque a arte jornalística não pode jamais estar desgarrada do mergulho na investigação, Elvira Lobato registra ainda na introdução do seu trabalho que a diferença entre a apuração rotineira e a investigação jornalística,

é o fato de que a segunda pressupõe, além de grande esforço de apuração, o furo da reportagem e a descoberta de fatos de interesse público que estavam ocultos. Não há nessa diferenciação nenhum juízo de valor quanto à qualidade do trabalho jornalístico. Existem reportagens com apurações brilhantes que não são investigativas (p. 8). 


\section{Reportagens analisadas}

O livro traz 11 reportagens escolhidas pela autora e publicadas na Folha de S. Paulo. Além dos fac-símiles da chamada de capa e da reportagem dentro do jornal, o título traz ainda todas as matérias de repercussão publicadas em dias posteriores.

No entanto, o essencial na publicação fica reservado para os bastidores da elaboração das reportagens. A autora detalha como surgiram as ideias da pauta, que tipo de preparação anterior foi necessário para iniciar-se o trabalho de apuração, incluindo-se discussões com a retaguarda jurídica sobre fontes em off, disfarces, conversas gravadas por telefone, entre outras coisas. Claro que o enfoque na necessidade do trabalho de equipe em praticamente toda reportagem investigativa também permeia cada um dos capítulos, assim como as reflexões sobre como editar tais reportagens. Mais importante ainda: em alguns capítulos, a autora acrescenta o resumo de conversas recentes que teve com as fontes que lhe auxiliaram na época da elaboração de algumas dessas reportagens.

As 11 reportagens publicadas são as seguintes, na mesma ordem do sumário do livro:

1) Programa nuclear da Serra do Cachimbo

2) República dos usineiros

3) Uso de funcionários públicos na eleição de Collor

4) Caso Banespa

5) O golpe das concessões de rádio

6) A TV virou cassino

7) A Igreja Universal e os paraísos fiscais

8) Os evangélicos que queriam comprar a Vasp

9) O dia seguinte de uma chacina

10) Políticos ganham TV na gestão tucana

11) Uma TV para Gugu Liberato

\section{Quando o off vale}

É no primeiro capítulo do livro que surge a reportagem apontada pela própria Folha de S. Paulo entre as seis mais importantes da história do Grupo
Folha. Referimo-nos à matéria sobre o programa nuclear da Serra do Cachimbo, quando Elvira Lobato descobriu que o Ministério da Aeronáutica havia construído instalações secretas, para testes de explosão atômica, no coração da Amazônia. "Brasil prepara local de teste nuclear", dizia a manchete, ilustrada com um mapa do sul do Pará, em que se destacava a base aérea da Serra do Cachimbo, região do campo de provas.

A autora esclarece que a redação final do texto foi do diretor da sucursal do Rio de janeiro, Marcelo Beraba, e do diretor de redação, Otavio Frias Filho. O material foi preparado a partir de 20 laudas de texto de Elvira, cuja confirmação de dados teve a contribuição de Gilberto Dimenstein e Roberto Lopes, especialista em assuntos militares.

A reportagem principal - ressalta a autora - foi elaborada a partir de dados técnicos e de informações obtidas em off. Por esse motivo, foi essencial o trabalho dos demais profissionais que confirmaram a existência e a finalidade do poço junto a militares de alta patente. A confirmação com várias fontes deu segurança de veracidade da apuração.

O sigilo das fontes estendeu-se ao sigilo dos autores da matéria. A direção do jornal optou por esse caminho por questão de segurança. A matéria não foi assinada, não havendo citação específica nem mesmo da sucursal do Rio.

Quanto à repórter Elvira Lobato, caso desejasse conhecer os detalhes da movimentação na Serra do Cachimbo, teria que permitir um grampo no seu telefone e assinar um documento responsabilizandose pelo não vazamento da informação. Preferiu não saber os detalhes.

O texto, portanto, não apresenta fontes. Todo o material publicado é assumido pelo veículo, motivo provável do ceticismo no tratamento dado por outros veículos. "Até os repórteres dos outros jornais que cobriam os desmembramentos do caso o consideravam invenção da Folha", frisa a autora na página 13.

Cabe aqui uma reflexão. Os repórteres precisam sempre ter muito cuidado ao lidar com fontes que optam por não se identificar. Por isso, registramos aqui algumas recomendações que, provavelmente, sempre revestirão as reportagens de maior credibilidade junto ao receptor.

\footnotetext{
1 Forma resumida de off the record, em português, fora de registro. Termo utilizado para designar uma fonte que exija o anonimato
} na matéria. 
Primeiramente, é necessário trabalho de convencimento da fonte para que se identifique. Em caso de impossibilidade, o ideal seria recorrer a outro testemunho. Na certeza de que o offé indispensável, cabe, então, cercá-lo da maior fidedignidade possível. Entre os caminhos, o repórter deve descrever em quais circunstâncias conseguiu tais informações, por que o offé fundamental, onde e de que forma foi feita a entrevista e até dar uma descrição da fonte, claro, sem evidenciar pistas que possam vir a desvendar o autor da informação. Mais ainda: o repórter deve checar o que lhe foi revelado pelo menos com mais uma fonte. Tais procedimentos devem ser discutidos com o editor e, dependendo da situação, contar também com a consultoria do setor jurídico do veículo.

\section{Especialização e investigação}

A importância de o jornalista ter pleno conhecimento do assunto que investiga fica evidente no segundo capítulo do livro, quando Elvira discorre sobre a República dos Usineiros, série publicada em 1989, no início da campanha eleitoral para a Presidência da República, "sobre o acordo para devolução de US\$120 milhões aos usineiros de Alagoas, que Fernando Collor assinou pouco antes de deixar o governo do Estado para a eleição".

A autora demonstra como foi importante especializar-se nos meandros do setor açucareiro. Ela estudou história e legislação da área a fim de conhecer bem o setor e descobrir as falcatruas e contradições que poderiam estar ocorrendo ali, o que realmente aconteceu. Segundo Elvira, o repórter

não pode depender apenas de conhecimentos de terceiros, porque corre o risco de ser induzido a erros. Além disso, é preciso ter segurança quanto ao teor da matéria para escrever o texto de forma clara. Ninguém consegue escrever de forma simples algo que considera complicado (p. 46).

A autora cita ainda outra decisão que contribuiu para a elaboração da reportagem, um hábito que adquiriu e não mais largou a partir daquela época: ler o Diário Oficial da União, ${ }^{2}$ periódico que traz as medidas adotadas pelo governo. "Em inúmeras ocasiões descobri pautas no Diário Oficial”, frisa na página 47.

\section{Acesso a documentos}

Outra fonte rica para apurações de caráter investigativo são os documentos públicos. Na reportagem sobre o uso de funcionários públicos na eleição do então presidente Fernando Collor de Mello, tal expediente fica bastante claro. Como se tratava de uma acusação grave contra um presidenciável, provas irrefutáveis precisariam ser obtidas.

Elvira foi ao protocolo da Assembleia Legislativa de Alagoas e fez requerimento formal querendo saber sobre a situação de alguns funcionários. Em 48 horas, recebeu a certidão assinada confirmando que um desses servidores não havia se licenciado para acompanhar o candidato em suas viagens por todo o País (o que comprovadamente vinha ocorrendo) e continuava a receber salário do Estado.

Para tornar a prova oficial, Elvira Lobato autenticou as cópias em cartório. Segundo a própria autora explica, documentos como provas valem tanto para a reportagem quanto para a defesa em um eventual processo na Justiça.

A primeira matéria da série foi publicada no dia 9 de setembro, um sábado, ilustrada com os facsímiles fornecidos pela Assembleia Legislativa e por um comprovante do salário de um dos militares que acompanhavam o ex-presidente Collor. Na mesma edição, foi publicado artigo de um advogado mostrando por que a participação dos funcionários era irregular.

\section{Falsidade ideológica}

$\mathrm{Na}$ quinta reportagem analisada, em que Elvira Lobato, em parceria com Josias de Souza, desvenda o golpe das concessões de rádio, dois pontos fundamentais são enfocados: a questão da falsidade ideológica e a gravação de telefonemas.

\footnotetext{
2 Os Diários Oficiais, mesmo aqueles municipais, trazem sempre todas as medidas tomadas pelo Governo. Desde nomeações, lista de aprovações em concursos, transferências de servidores, até abertura de licitações. A sua leitura frequente e atenta gera, com certeza, pautas fundamentais para aqueles que se dispõem a uma grande investigação. As edições que circulam em dias de mais difícil acesso ao veículo, aos sábados, por exemplo, costumam ser as preferidas pelos jornalistas investigativos. Nesses dias, é comum aparecer nas páginas do veículo oficial os fatos que a administração no poder mais gostaria de ocultar.
} 
A autora admite ter usado nomes e profissões fictícias e ter gravado conversas sem o conhecimento da outra parte a fim de apurar a sua reportagem. Contudo, ela segue um ritual para isso, respondendo, por exemplo, a algumas perguntas: $\mathrm{O}$ assunto é de interesse público? É jornalisticamente importante? A sociedade ganhará com a revelação desse fato? "Nosso trabalho é buscar a informação, e não evitá-la. Se a direção da Redação discordar do método utilizado, pode vetar a publicação da matéria. Mas o repórter terá feito o seu trabalho" (p. 111).

Nesse capítulo, a jornalista mostra ainda como tais recursos são encarados pela Justiça. Em relação às conversas telefônicas gravadas, sem o conhecimento de uma das partes, há juízes que aceitam como prova de acusação, enquanto outros refutam.

No tocante a usar nome falso, o repórter pode vir a ser acusado de falsidade ideológica, mas se ficar demonstrado que usou o recurso apenas para trazer à tona um fato de interesse público, é grande a possibilidade de os juízes arquivarem a ação contra ele.

No referido capítulo, Elvira recorre ao advogado Luís Francisco Carvalho Filho, consultor da Folha. Segundo ele, há situações excepcionais em que o interesse público justifica o uso de nome fictício e a gravação de conversas telefônicas, mas a decisão deve ser tomada com o conhecimento da direção do órgão de imprensa. O que se critica é o abuso na utilização desses recursos.

\section{Cuidados na favela}

Um dos capítulos mais interessantes do livro é aquele em que a autora focaliza em uma matéria cuja investigação tem como palco as imediações da favela Caixa d'Água, na zona norte do Rio de Janeiro. Tratava-se da maior chacina do Rio de Janeiro desde 1995.

Elvira Lobato conta como conseguiu entrar na favela, incógnita, e encontrar uma maneira de falar com moradores sem despertar atenção. A estratégia foi conseguir o apoio de uma das lideranças religiosas no local. Com uma condição: ninguém, nem mesmo o nome da entidade religiosa, seria identificado na reportagem. Combinou-se também que a repórter chegaria sozinha, como se fosse membro da igreja. nenhum deles, para deixar claro que o compromisso de sigilo das fontes seria cumprido [...]. Graças aos relatos, consegui descrever o clima de terror existente na favela (p. 222).

Impossível não lembrar do que ocorreu com o jornalista Tim Lopes, repórter da TV Globo, executado em 2002, na Vila Cruzeiro, uma das favelas do Complexo do Alemão. A morte do jornalista, segundo a autora, levou os órgãos de imprensa a reforçar os procedimentos de segurança para a entrada de jornalistas nas favelas. Entre esses procedimentos, estão a determinação de só entrar no local em equipes, usar coletes à prova de balas e não se expor a risco.

Elvira Lobato declara que:

o assassinato de Tim Lopes nos ensinou que a avaliação das condições de segurança deve ser feita em conjunto com a chefia, a qual precisa estar informada sobre todos os passos da equipe, enquanto ela estiver na área de risco. $\mathrm{Na}$ empolgação pelo furo, alguns repórteres entre os quais me incluo - tendem a minimizar os riscos de segurança e a chefia pode trazê-los à realidade nessas situações (p. 223).

A declaração da autora do livro leva a uma outra reflexão. O compromisso do jornalista é descobrir a verdade oculta e levá-la ao conhecimento pleno do público receptor. E essas pessoas não estão muito interessadas em atos de heroísmo dos jornalistas. O que lhes interessa é a verdade dos fatos e ponto final. O livro de Elvira é, no mínimo, leitura obrigatória porque incentiva a investigação jornalística e serve de bússola para os veículos à deriva entre publicar material pasteurizado ou investir definitivamente nas reportagens aprofundadas. Que navegue em mar tranquilo, a segunda e única opção.

Recebido: 25/03/2010

Received: 03/25/2010

Aprovado: $15 / 04 / 2010$

Approved: 04/15/2010

Conversei com os moradores em uma sala reservada da igreja e não anotei o nome de 